\title{
Evaluación de la cohesión de betunes modificados con polvo de neumáticos
}

\section{Cohesion in crumb rubber modified bitumen}

\author{
F. Pérez-J iménez(*), R. Miró Recasens ${ }^{(*)}$, A. Martínez(*), C. Martínez Laínez(*) y A. Páez Dueñas(*)
}

\section{RESUMEN}

El objetivo de este artículo es estudiar la influencia del polvo de neumático en la mejora de la cohesión proporcionada por la adición del polvo de neumático al betún mediante el método UCL. El método UCL es un procedimiento desarrollado para caracterizar ligantes bituminosos, basado en la evaluación de la cohesión dada por una cantidad determinada de un betún o un mástico bituminoso a unos áridos de granulometría establecida (mezcla patrón). Se ha empleado este método porque permite valorar al mismo tiempo los dos procedimientos de incorporación del polvo de neumático al betún: vía seca y vía húmeda.

El procedimiento seco se lleva a cabo añadiendo el polvo de neumático a la mezcla como si fuera un filler, de modo que el polvo de neumático y el ligante se mezclan durante la fabricación, extendido y compactación de la mezcla. En el procedimiento húmedo, hay una mezcla previa del ligante con el polvo de neumático, por lo que aquél se añade a la mezcla cuando ya ha sido modificado. También se ha estudiado la influencia de los tiempos de digestión. Se comparan los dos procedimientos, seco con y sin digestión, y húmedo. El segundo presenta una clara ventaja, especialmente cuando los ligantes son fabricados con dispersión microscópica.

Palabras clave: polvo de neumático, betún, filler, cohesión, método UCL.

\section{SUMMARY}

This article reports on a study of crumb rubber-mediated improvement in bitumen cohesion, analyzed with the UCL method. UCL, a procedure developed to characterize bituminous binders, evaluates the cohesion obtained by adding a certain amount of bitumen or bituminous mastic to a standard mix aggregate. This method was chosen because it can be used to assess bitumen containing crumb rubber added by either the wet or the dry mix process.

In the dry mix process crumb rubber is combined with the mix as if it were a fine aggregate; i.e., crumb rubber and binder are blended during mix manufacture, laying and compaction. In the wet mix process, the binder is blended with the crumb rubber prior to mixing with the aggregate; i.e., when added to the mix, it has already been modified. The effect of digesting this dry mixed material prior to use was also analyzed in the present study. A comparison of the dry (with and without digestion) and wet mix processes showed the latter to be more effective, particularly when the crumb rubber was blended with the binder via microscopic dispersion.

Keywords: crumb rubber, bitumen, filler, cohesion, UCL method.

(*) Laboratorio de Caminos. Universidad Politécnica de Cataluña. Barcelona, España. 


\section{INTRODUCCIÓN}

Los países occidentales se enfrentan a un serio problema de acopio de neumáticos usados y es por ello que se ha propuesto su utilización como un componente de las mezclas asfálticas.

Se sabe que el polvo de neumáticos mejora las propiedades reológicas del asfalto (1) y es la razón por la que este residuo se ha venido utilizando desde la década del sesenta en diferentes tipos de aplicaciones: modificación de betunes para el sellado de fisuras de pavimentos, ligantes para tratamientos superficiales, riegos y membranas (2). Los estados de Florida, California y Arizona emplean el polvo de neumáticos en cementos asfálticos en contenidos que varían desde un 5 a un 30\%, tanto en mezclas densas como porosas, especialmente en tratamientos superficiales (3).

En las últimas décadas muchos investigadores han estudiado este producto, analizando su comportamiento mediante ensayos clásicos, como por ejemplo el Marshall (4), ensayos para evaluar su deformación permanente, su resistencia (5) o su contribución al incremento del módulo del betún o la mejora de la vida a fatiga (6). Sin embargo, se han realizado pocos estudios sobre una de las propiedades más importantes que el polvo de neumáticos otorga a las mezclas, como es la cohesión.

Aunque el término "cohesión" puede asociarse con la resistencia al corte de los materiales, también puede ser utilizado, en el ámbito de las mezclas bituminosas, para describir el poder aglomerante de los ligantes y es con este significado que el término "cohesión" se ha utilizado en este estudio.

Existen ensayos que pretenden evaluar esta cohesión o poder aglomerante que el ligante proporciona a la mezcla (cohesiómetro Hveem, ensayo de tracción indirecta, etc.), pero estos ensayos no tienen en cuenta la deformación que experimenta la mezcla en su rotura, ni mucho menos, el trabajo de rotura. Sin embargo, en el caso de los ligantes y mezclas bituminosas esta propiedad es fundamental, porque las uniones que proporciona no son fuertes ni de una elevada rigidez, como es el caso de los ligantes hidráulicos, sino dúctiles y tenaces, que requieren una gran deformación y trabajo para su rotura. Cuando se modifica un betún para su empleo en mezclas tipo SMA o porosas, se mejora su ductilidad y tenacidad, pero no su rigidez y resistencia pico a rotura, que muchas veces disminuyen. Esto lleva a que cuando se emplean ensayos que valoran únicamente la estabilidad o el módulo en la dosificación de estas mezclas se obtienen resultados contradictorios.

En el año 1979, Pérez-Jiménez desarrolló, en el Laboratorio de Caminos de la Universidad de Cantabria, un

\section{INTRODUCTION}

One possible solution to the problem posed by the growing stockpile of used tyres in Western countries is their use as a component in asphalt mixes.

Since the nineteen sixties crumb rubber has been known to improve the rheological properties of bitumen (1) and has been used in different types of applications: modification of bitumen for sealing pavement cracks, binders for surface dressings, sprays and membranes (2). Crumb rubber, in proportions ranging from 5 to 30\%, is used in asphalt cement in the states of Florida, California and Arizona for both open- and dense-graded mixes, particularly in surface dressings (3).

This product has been the object of much research in recent decades and its performance analyzed with classic methods such as the Marshall test (4) as well as trials to evaluate rutting, strength (5) or its contribution to improving the modulus or lengthening the fatigue life of bitumen (6). And yet very few studies have been conducted on one of the most important asphalt mix properties impacted by the addition of crumb rubber, namely cohesion.

Although sometimes associated with material shear strength, the term cohesion may also be used in the context of asphalt mixes to describe the bonding power of binders: this is the meaning attributed to the word in the present study.

A number of trials attempt to evaluate the cohesion or bonding power provided by the binder (Hveem cohesiometer, indirect tensile strength test and so on) but take no account of failure deformation and much less of failure energy. But this is an essential property in bituminous binders and mixes, because the bonds formed are neither as strong nor as stiff as in hydraulic binders. Rather, they are ductile and tough and can therefore withstand a great deal of strain and energy before they fail. When bitumen is modified for use in SMA (stone mastic asphalt) or open-graded mixes, its ductility and toughness are improved, but not its rigidity or peak strength, which often decline. Consequently, the results of design test that assess only the stability or modulus of these mixes are often contradictory.

In 1979, Pérez-J iménez developed a simple trial in the University of Cantabria's Civil Engineering Laboratory, 
ensayo sencillo, "ensayo cántabro", para diseñar mezclas porosas (7-8). Como se indica anteriormente, hasta ese momento, los ensayos para dosificar y caracterizar mezclas bituminosas estaban basados, en la mayoría de los casos, en la valoración de su estabilidad, pero no había procedimientos para evaluar el efecto del ligante en la resistencia a la disgregación de estas mezclas, que es el mecanismo de fallo más frecuente, propiedad que se valora en el ensayo cántabro.

El ensayo cántabro consiste en introducir en el tambor de los Ángeles una probeta cilíndrica, tipo Marshall, de mezcla porosa y someterla a 300 revoluciones del tambor sin ningún tipo de carga abrasiva. Por efecto del impacto de la probeta contra las paredes del tambor se va produciendo la pérdida de los áridos de la mezcla en la superficie de la probeta. Cuanto mayor sea la capacidad del betún para absorber la energía del impacto (deformándose elástica o plásticamente), menor será el número de partículas que se desprendan y consecuentemente menor será la pérdida de peso de la probeta, determinada como porcentaje respecto al peso inicial. En definitiva, el ensayo evalúa experimentalmente la capacidad que tiene el betún o el mástico asfáltico para mantener cohesionados o aglomerados los áridos de la mezcla.

Actualmente el ensayo cántabro está recogido en la mayoría de la normativa mundial (prEN 12697-17, ASTM Standard Practice for Open Graded Friction Course (OGFC) Mix Design) y es utilizado en la dosificación de mezclas porosas y microaglomerados (mezclas tipo SMA).

En el año 1989, los profesores Miró y Pérez-Jiménez empezaron en el Laboratorio de Caminos de la Universidad Politécnica de Cataluña una nueva línea de investigación dirigida a la aplicación del ensayo cántabro a la caracterización de ligantes. Fruto de esta investigación fue el desarrollo del método UCL (Método Universal de Caracterización de Ligantes) (9-11), que consiste en valorar la cohesión que una cantidad fija de ligante proporciona a una mezcla patrón de granulometría y composición fija y ver cómo esta cohesión varía con la temperatura, la presencia de agua o por el envejecimiento del ligante. Los resultados obtenidos han sido excelentes, dada la alta sensibilidad, repetibilidad y reproducibilidad del ensayo (12), que permite comparar gráficamente y de forma sencilla el comportamiento de todo tipo de betunes, tanto convencionales como modificados.

El método UCL puede ser también aplicado a la valoración del efecto del filler, en el caso de los másticos bituminosos. El filler es un elemento esencial de las mezclas bituminosas, ya que es el componente que se mezcla más íntimamente con el ligante, modificando su reología y comportamiento. Normalmente, la caracterización del filler se hace independientemente del ligante, sin tener known as the "cantabro test", for the design of porous asphalts (7-8). As noted above, until that time the tests for design and characterizing bituminous mixes were usually based on an evaluation of their stability. No procedures were in place, however, to evaluate the effect of the binder on mix disgregation, the most common cause of failure and the property assessed with the cantabro test.

This test consists in rotating a Marshall-type, cylindrical porous asphalt specimen in a Los Angeles rattler, without abrasives, at $300 \mathrm{rpm}$. The impact of the specimen against the walls of the drum dislodges the surface aggregate in the mix. The greater the capacity of the bitumen to absorb the impact energy (via elastic or plastic deformation), the fewer particles are dislodged and consequently the lower the weight loss in the specimen, expressed in percentage of initial weight. The test, in short, evaluates the capacity of the bitumen or asphalt mastic to bind the aggregate.

The cantabro test is presently included in most international standards (prEN 12697-17, ASTM Standard Practice for Open Graded Friction Course (OGFC) Mix Design) and is used to determine the dosage of porous and SMA type asphalts.

In 1989 Professors Miró and Pérez-Jiménez undertook a new line of research at the Technical University of CataIonia's Road Research Laboratory to use the cantabro test to characterize binders. The result of this research was the development of the UCL (Spanish initials for (método) universal de caracterización de ligantes, universal binder characterization) method (9-11). This procedure is used to evaluate the cohesion conferred by a given amount of binder on a standard mix with a fixed gradation and composition and the variation in such cohesion with temperature, water penetration or binder ageing. Excellent results were obtained, for the high sensitivity, repeatability and reproducibility of the test (12) made it possible to graphically compare the performance of all manner of conventional and modified asphalts.

The UCL method may also be applied to evaluate the effect of filler on bitumen mastics. Filler are an essential element of bituminous mixes because they are the component that bond most closely to the binder, modifying its rheology and behaviour. Normally, filler are characterized separately from the binder with no account taken of the effect that the possible interaction between their 
en cuenta las posibles interacciones que las propiedades de uno y de otro pueden tener en el comportamiento conjunto. El método UCL permite valorar este comportamiento conjunto, ya que igual que se valora el efecto aglomerante de un betún sobre una mezcla patrón, puede valorarse también el efecto de una cantidad fija de mástico sobre esa misma mezcla patrón. Se puede así valorar la influencia del filler para ir cerrando huecos en la mezcla y cómo afecta a la susceptibilidad y al poder aglomerante del ligante.

El método UCL ha sido aplicado en el análisis de los betunes modificados con polvo de neumático. La modificación de los betunes asfálticos con neumático puede realizarse por dos vías, una, añadiendo el polvo de neumático directamente a la mezcla como si se tratase de un filler, vía seca, de forma que el polvo de neumático y el betún se combinen e interaccionen durante la fabricación, extendido y compactación de la mezcla. La otra vía consiste en añadir el polvo de neumático previamente al betún, vía húmeda, y modificar éste antes de añadirlo a la mezcla (13).

El efecto del polvo de neumático sobre el betún puede ser evaluado mediante el método UCL de las dos maneras, ya que permite ver su efecto sobre el poder aglomerante del ligante cuando se incorpora como filler o cuando se parte de un betún modificado en planta. En este artículo se exponen los resultados obtenidos en el análisis del efecto del polvo de neumático sobre el comportamiento de un ligante, que ha sido modificado por los dos procedimientos, vías seca y húmeda, variando incluso los tiempos de digestión del producto.

Previo a estos resultados se presenta de forma reducida el método UCL, para facilitar mejor la comprensión y valoración de los resultados obtenidos.

\section{MÉTODO UCL}

El método UCL está basado, como se ha indicado anteriormente, en valorar la cohesión que una cantidad fija de betún proporciona a unos áridos de granulometría y composición fija (mezcla patrón). Desde el inicio del método, la granulometría empleada estaba compuesta fundamentalmente por un elevado porcentaje de partículas gruesas y una pequeña cantidad de arena sin finos. Es decir, se trataba de cohesionar partículas del mismo tamaño con una cantidad fija de betún, siendo la función de la arena cerrar y dar una mayor resistencia a la disgregación a la mezcla. Al ser una arena sin finos no se forma ningún tipo de mástico y la película fina que envuelve estos áridos es únicamente de betún. Después de numerosos ensayos sobre distintos tipos de granulometría, se fijó una granulometría patrón compuesta por respective properties may have on their joint behaviour. The UCL method evaluates such joint behaviour since it can be used to evaluate not only the bonding effect exerted by a bitumen, but also the impact of a fixed amount of bitumen mastic on a standard mix. The capacity of filler to close gaps in the mix can also be assessed, along with their effect on binder susceptibility and bonding power.

The UCL method was applied in the present study to analyze crumb rubber modified bitumen. There are two processes for modifying bituminous asphalts with crumb rubber: in one, the dry mix process, crumb rubber is added directly to the mix as if it were a fine aggregate, so rubber and bitumen combine and interact during manufacture, laying and compaction. The other consists in blending the crumb rubber and bitumen prior to mixing with the aggregate. This is known as the wet mix process (13).

The UCL method analyzes the effect of crumb rubber on bitumen regardless of the process used, for it detects its impact on binder bonding power both when it is included as a fine aggregate and when the bitumen is modified at the plant. This article discusses the results obtained in a study of the impact of crumb rubber on binder performance under both the dry and wet mix process conditions and at different digestion times.

That discussion preceded by a brief description of the UCL method to enhance the comprehensibility and evaluation of the results obtained.

\section{UCL METHOD}

As indicated above, the UCL method is based on evaluating the cohesion conferred by a fixed amount of bitumen to aggregate with a fixed grading and composition (standard mix). Ever since the method was devised, the gradation used has consisted primarily in a high percentage of coarse aggregate and a small amount of sand with no filler. In other words, the aim was to bind particles of the same size to a fixed amount of bitumen, where the purpose of the sand was to close gaps and increase the capacity of the mix to resist disintegration. Since the sand contained no filler, no mastic was formed and the thin film surrounding the aggregate was one hundred per cent bitumen. After numerous tests with different particle size distributions were conducted, a standard gradation was defined, consisting of $80 \%$ 2.5/5- $\mathrm{mm}$ 
un $80 \%$ de árido de tamaño 2,5/5 mm y un $20 \%$ de árido de tamaño $0,63 / 2,5 \mathrm{~mm}$ por ser la que proporcionaba una gran repetibilidad y reproducibilidad al ensayo.

El árido empleado debe tener un desgaste de Los Ángeles bajo, menor de 20, para que no se rompa durante la compactación y fabricación de las probetas. El contenido de betún sobre árido es del 4,5\%. Así se obtiene un contenido de huecos en mezcla de un $27 \pm 1 \%$.

Uno de los principales resultados que se obtiene del método UCL cuando se aplica a la caracterización de los ligantes bituminosos es la curva de estado. Cuando se realiza el ensayo de las probetas a diferentes temperaturas se observa que, cuando la temperatura es inferior a $20 \stackrel{\circ}{ } \mathrm{C}$-dependiendo del tipo y penetración del betún-, se produce una fragilización y pérdida de tenacidad del betún, aumentando las pérdidas al cántabro. Cuando aumenta la temperatura por encima de estos valores, el betún pierde consistencia y disminuye su capacidad para mantener las piedras unidas, aumentando de nuevo las pérdidas.

El procedimiento normalmente seguido en el ensayo de estas probetas consiste en mantener las probetas en frigorífico y/o estufa durante 4-8 horas a la temperatura de ensayo e introducir rápidamente las probetas, en la máquina de Los Ángeles, situada en una cámara a la temperatura de $25 \stackrel{\circ}{ }$ C. La variación de la temperatura durante el ensayo es siempre la misma y se obtienen muy pocas variaciones en los resultados de las probetas ensayadas.

La curva de estado refleja claramente el comportamiento del betún como aglomerante en un amplio rango de temperaturas. Cuanto más baja sea la curva de estado y menor sea su pendiente al variar la temperatura, mejor será el comportamiento esperado del betún. En la Figura 1 se representan las curvas de comportamiento de diferentes tipos de betunes, betunes asfálticos de penetración B-10/20 a B-250/300 y diferentes tipos de betunes modificados con polímeros para mezclas tipo SMA y porosas.

Las curvas de estado de los betunes modificados claramente se sitúan en la parte más baja de la figura, con menores pérdidas y curvas más tendidas. Si observamos los betunes asfálticos de penetración, sus curvas giran sobre la pérdida a temperatura ambiente (10-25 으). A temperaturas bajas son los betunes más duros los que mayores pérdidas tienen, mientras que a altas temperaturas ocurre al revés.

El ensayo tiene una gran sensibilidad para poner incluso de manifiesto las variaciones de comportamiento de betunes de la misma penetración y diferente índice de penetración. Cuanto menor es éste, mayor es la pendiente de la curva de estado. Esta sensibilidad del ensayo para aggregate and $20 \% \quad 0.63 / 2.5-\mathrm{mm}$ aggregate. This made the test highly repeatable and reproducible.

The aggregate used must have a low Los Angeles abrasion value, under 20 , to withstand compaction and specimen manufacture without breaking. A bitumen content of $4.5 \%$ of the aggregate yields a voids content of $27 \pm$ $1 \%$.

One of the main outputs of the UCL method when used to characterize bituminous binders is the performance curve. When specimens are tested at temperatures below $20{ }^{\circ} \mathrm{C}$, depending on bitumen type and penetration, asphalt fragility grows and toughness declines, with a concomitant increase in Cantabro test weight loss. At temperatures of over these values, the loss of bitumen consistency reduces its capacity to hold the aggregate together, also leading to greater weight loss.

The procedure usually followed in this test is to keep the specimens refrigerated and/or in a stove for 4-8 hours at the test temperature, and then place them immediately in the Los Angeles rattler, in turn located in a controlled temperature $(25 \stackrel{\circ}{ }$ ) chamber. This ensures that temperature variations during the test are always the same and only minor differences are observed in the results for the specimens tested.

The resulting curve clearly reflects bitumen bonding performance across a wide range of temperatures. The lower the performance curve and the smaller its slope with temperature variations, the better is the expected performance of the bitumen. Figure 1 shows the performance curves for different types of bitumen: $B-10 / 20$ to $B-250 / 300$ penetration asphalts and several varieties of polymer-modified bitumen for SMA and porous mixes.

The performance curves for the modified bitumen are clearly flatter and positioned on the lowest part of the figure, indicating lower losses. In the penetration bitumen curves, the loss at ambient temperature (10-25 ㅇ) marks a clear difference in behaviour. At lower temperatures they are the hardest materials with the highest losses, while at higher temperatures the opposite is observed.

The test is also sensitive enough to detect variations in the behaviour of bitumen specimens with the same penetration but different penetration indices. The lower the index, the steeper is the performance curve slope. Such test sensitivity to these variations in behaviour 


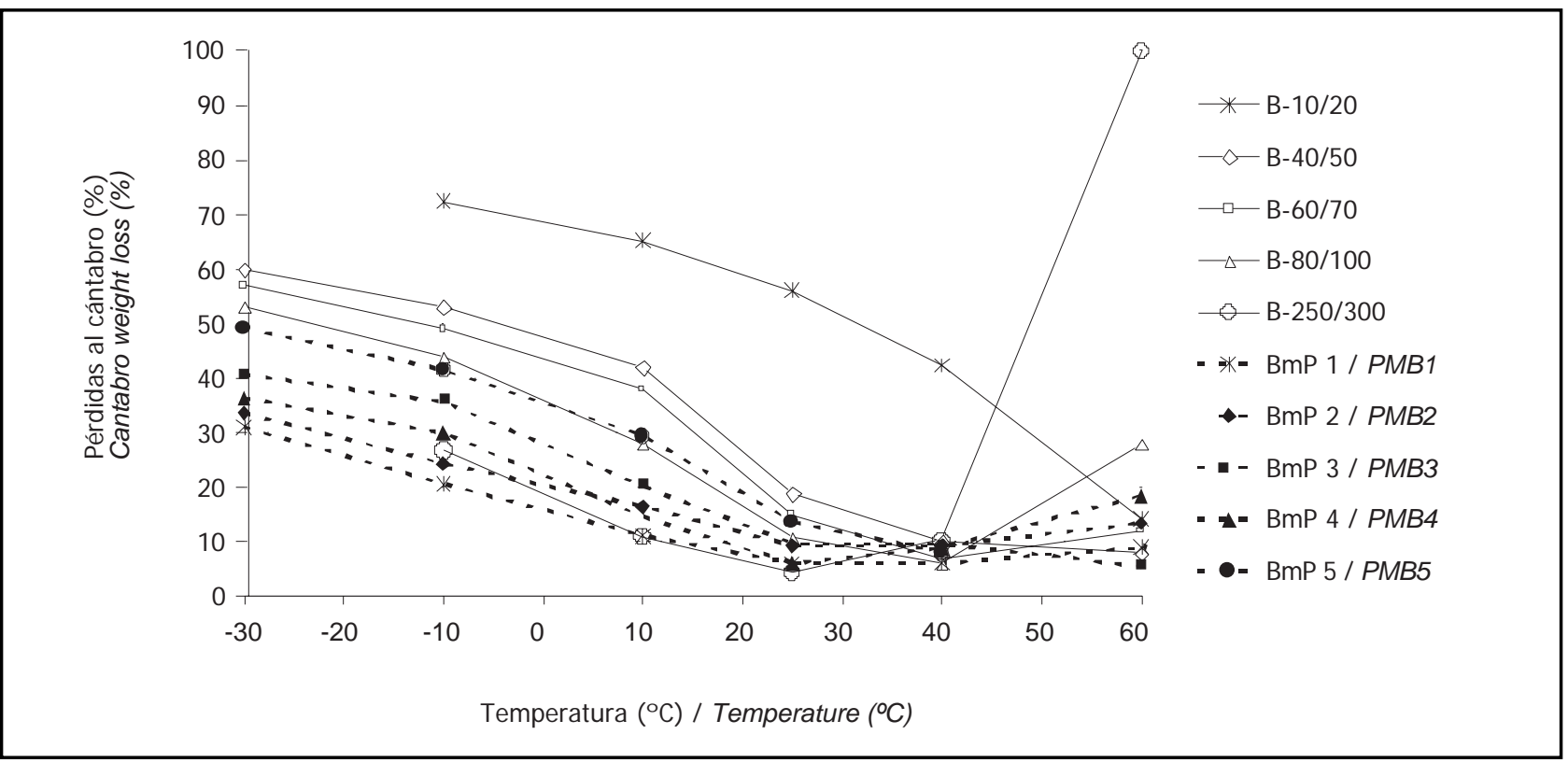

Figura 1. Curvas de comportamiento UCL para diferentes tipos de betunes.

Figure 1. UCL performance curves for different types of bitumen.

apreciar estas variaciones de comportamiento va unida a la gran repetibilidad y reproducibilidad del mismo (12).

El método UCL puede ser también empleado en la valoración del efecto del filler para modificar el comportamiento del betún en la mezcla. Dado su tamaño, menor de $0,063 \mathrm{~mm}$, se introduce en la película de betún, modificando y cambiando su comportamiento. El efecto que normalmente tiene el filler es el de modificar la viscosidad del betún, aumentando su resistencia a la rotura y disminuyendo su ductilidad, efecto que depende de la finura del filler, de su naturaleza y de la relación volumétrica filler/betún.

Para el análisis del efecto de filler en la cohesión del ligante se ha considerado el procedimiento desarrollado por el profesor Ruiz (14-15). En este procedimiento se determina, mediante un ensayo de sedimentación, el volumen máximo de filler que se puede emplear para rellenar la película de betún, de forma que éste quede siempre en su interior. Con respecto a esta concentración máxima, denominada concentración crítica $\left(C_{s}\right)$, se ha analizado el efecto de la concentración volumétrica $\left(C_{v}\right)$ y la naturaleza del filler sobre el poder aglomerante del ligante. Ambos parámetros se determinan mediante las siguientes expresiones: goes hand-in-hand with its repeatability and reproducibility (12).

The UCL method may also be used to evaluate the effect of filler in modifying bitumen behaviour in the mix. Given their size, under $0.063 \mathrm{~mm}$, they penetrate the bitumen membrane, modifying and changing its behaviour. The effect of filler is usually to modify bitumen viscosity, increasing its mechanical strength and decreasing its ductility; these effects depend on the fineness and nature of the fine aggregate and the filler/bitumen ratio, by volume.

The procedure developed by Professor Ruiz (14-15) was used to analyze the effect of the filler on binder cohesion. This technique consists in conducting a sedimentation test to determine the maximum volume of filler that the bitumen membrane can accommodate in its interior. The effect of the volume concentration $\left(C_{V}\right)$ and nature of the filler on binder bonding power was analyzed in terms of the above maximum or critical concentration $\left(C_{S}\right)$. These two parameters are defined as follows:

$$
\begin{aligned}
& \mathrm{C}_{\mathrm{s}}=\frac{P}{V \cdot \gamma} \\
& \mathrm{C}_{\mathrm{v}}=\frac{V_{\text {ol }}}{\mathrm{Vol}_{\text {filler }}}
\end{aligned}
$$


siendo

$P$ : peso de la muestra de filler ensayada

$V$ : volumen aparente de la muestra de filler, determinado por sedimentación en keroseno deshidratado a las 24 horas

$\gamma$ : peso específico del filler

Vol filler: volumen ocupado por el filler en el mástico

Vol betún: volumen ocupado por el betún en el mástico

\section{APLICACIÓN DEL MÉTODO UCL}

\section{A LA CARACTERIZACIÓN DE BETUNES MODIFICADOS CON POLVO DE NEUMÁTICOS}

El método UCL permite analizar el efecto de polvo de neumático teniendo en cuenta el procedimiento de incorporación utilizado, ya que unas veces éste se añade por vía seca, como si se tratase de un filler que actuará con el ligante, y otras ha sido incorporado previamente al betún, obteniéndose un betún modificado. En ambos casos, obtener las curvas de estado de los ligantes modificados por el polvo de neumático, por vía seca y húmeda, permite comparar entre sí ambos procedimientos.

\section{Vía seca}

Se ha partido de un betún base B-60/70, al que se le ha añadido polvo de neumático de tamaño máximo $0,8 \mathrm{~mm}$ y polvo de SBS. En la Tabla 1 se resumen las características del betún base. where

$P$ : weight of the filler sample tested

$V$ : apparent volume of the filler sample, determined by sedimentation in dehydrated kerosene for 24 hours $\gamma$ : filler specific weight

Vol filler: volume occupied by the filler in the mastic

Vol bitumen: volume occupied by the bitumen in the mastic

\section{USE OF THE UCL METHOD TO CHARACTERIZE CRUMB RUBBER MODIFIED BITUMEN}

The UCL method can be used to analyze the impact of crumb rubber, regardless of whether it is added via a dry mix process, as if it were fine aggregate interacting with the binder, or a wet process, in a preliminary step that produces modified bitumen. Thanks to this feature, the performance curves obtained for dry and wet mix process crumb rubber modified bitumen can be compared.

\section{Dry mix process}

The base bitumen used was $B-60 / 70$, blended on the one hand with 0.8- $\mathrm{mm}$ (maximum) crumb rubber and with SBS on the other. The base bitumen characteristics are summarized in Table 1.

Tabla 1 / Table 1

Características de los betunes

Characteristics of the bitumen used

\begin{tabular}{|c|c|c|c|}
\hline & $\begin{array}{l}\text { Norma } \\
\text { Standard }\end{array}$ & B-60/ 70 & $\begin{array}{l}\text { BmPN } \\
(C R m B)\end{array}$ \\
\hline $\begin{array}{l}\text { Penetración (mm.10-1) } \\
\text { Penetration (mm.10-1) }\end{array}$ & NLT-124 & 60 & 65 \\
\hline $\begin{array}{l}\text { Punto de reblandecimiento } A \text { y } B(\stackrel{\circ}{ } C) \\
\text { Softening Point } R \& B(\stackrel{\circ}{ })\end{array}$ & NLT-125 & 52 & 58,7 \\
\hline $\begin{array}{l}\text { Índice de penetración } \\
\text { Penetration Index }\end{array}$ & NLT-181 & $-0,25$ & 1,5 \\
\hline $\begin{array}{l}\text { Fragilidad Fraass }(\stackrel{\circ}{ } \mathrm{C}) \\
\text { Fraass Fragility }(\stackrel{\circ}{\circ})\end{array}$ & NLT-182 & -14 & -19 \\
\hline $\begin{array}{l}\text { Recuperación elástica (\%) } \\
\text { Elastic Recovery (\%) }\end{array}$ & NLT-329 & & 42 \\
\hline 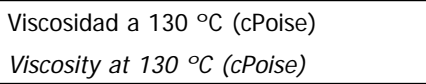 & NLT-375 & & 1802 \\
\hline 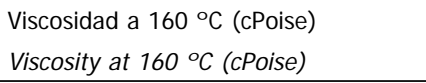 & NLT-375 & & 540 \\
\hline 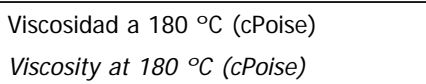 & NLT-375 & & 290 \\
\hline
\end{tabular}


Tabla 2 / Table 2

Formulaciones de las mezclas fabricadas utilizando la vía seca Properties of dry process mixes

\begin{tabular}{|l|c|c|c|c|c|c|}
\hline $\begin{array}{l}\text { Series } \\
\text { Series }\end{array}$ & $\mathbf{1}$ & $\mathbf{2}$ & $\mathbf{3}$ & $\mathbf{4}$ & $\mathbf{5}$ & $\mathbf{6}$ \\
\hline $\mathrm{C}_{\mathrm{v}} / \mathrm{C}_{\mathrm{s}}$ & 0 & 0,5 & 1,0 & 1,0 & $\left(^{*}\right)$ & $\left(^{*}\right)$ \\
\hline $\begin{array}{l}\text { Tipo de filler } \\
\text { Type of filler }\end{array}$ & - & $\mathrm{PN}(\mathrm{CR})$ & $\mathrm{PN}(\mathrm{CR})$ & $\mathrm{CaCO}_{3}$ & $\mathrm{SBS}$ & SBS \\
\hline $\begin{array}{l}\text { Peso de árido (g) } \\
\text { Aggregate weight (g) }\end{array}$ & 900 & 900 & 900 & 900 & 900 & 900 \\
\hline $\begin{array}{l}\text { Peso de ligante (g) } \\
\text { Binder weight (g) }\end{array}$ & 40,5 & 40,5 & 40,5 & 40,5 & 40,5 & 40,5 \\
\hline $\begin{array}{l}\text { Peso de filler (g) } \\
\text { Filler weight (g) }\end{array}$ & 0 & 3,71 & 8,03 & 46,69 & 3,71 & 8,03 \\
\hline $\begin{array}{l}\text { Relación filler/betún (\%) } \\
\text { Filler/binder ratio (\%) }\end{array}$ & & 9,2 & 19,8 & 115,3 & 9,2 & 19,8 \\
\hline
\end{tabular}

PN: Polvo de neumático $0,8 \mathrm{~mm} / \mathrm{CR}: 0.8-\mathrm{mm}$ crumb rubber.

(*) No se pudo calcular / This value could not be calculated.

En los dos casos, se han utilizado dos concentraciones diferentes. Las mezclas fabricadas con polvo de neumático y con polvo de SBS se han comparado con otra fabricada con un filler de aportación de carbonato cálcico y una que no contiene filler. En la Tabla 2 se resumen las formulaciones de las distintas mezclas fabricadas y ensayadas con el UCL.

\section{Vía seca con digestión}

En este caso se ha estudiado si el hecho de cambiar el procedimiento y el tiempo de fabricación podía influir en los resultados. Para ello se ha sometido a la mezcla a un proceso de digestión antes de ser compactada. Dicho proceso ha consistido en mantener la mezcla en estufa a $165 \stackrel{\circ}{ } \mathrm{C}$ durante 3 periodos de tiempo distintos $(0,1$ y 2 horas). La concentración volumétrica de filler/betún considerada ha sido de $\mathrm{Cv} / \mathrm{Cs}=0,5$.

\section{Vía húmeda}

Para el caso de vía húmeda, se han fabricado betunes modificados con polvo de neumático de dos formas distintas, en suspensión (fabricación en amasadora en laboratorio) y en dispersión microscópica (fabricación en planta con agentes estabilizadores).

Para la fabricación en suspensión se ha utilizado el mismo betún que se empleó en la vía seca. Al betún base se han añadido por amasado distintos porcentajes de polvo de neumático: 10, 15 y 20\%. La adición del polvo de neumá-

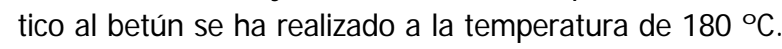

Las características del betún fabricado con el polvo en dispersión microscópica, denominado BmPN, se recogen en la Tabla 1.
Two different concentrations were used in both cases. The crumb rubber and SBS mixes were compared to an asphalt made with calcium carbonate filler and the same asphalt without filler. The composition of the various mixes tested are shown in Table 2.

\section{Dry mix process with digestion}

This experiment, conducted to study the possible effects on the results of changing the procedure and manufacturing time, involved subjecting the mix to digestion prior to compaction. The process consisted in storing the mix in a stove at $165{ }^{\circ} \mathrm{C}$ for three different periods of time (0, 1 and 2 hours). The filler/bitumen volume concentration used was $\mathrm{Cv} / \mathrm{Cs}=0.5$.

\section{Wet mix process}

Two procedures were used in the wet mix process: suspension (manufactured in a laboratory mixer) and microscopic dispersion (industrial manufacture with stabilizing agents).

The bitumen used was the same as for the dry mix process. Different percentages -10, 15 and 20\% - of crumb rubber were blended with the base bitumen at a temperature of $180^{\circ} \mathrm{C}$.

The characteristics of the microscopic dispersion-manufactured bitumen are shown in Table 1 under the heading CRMB. 


\section{ANÁLISIS DE RESULTADOS}

\section{Vía seca}

Los resultados del método UCL aplicados al betún modificado por vía seca han sido recogidos en la Figura 2, indicándose el contenido de huecos alcanzado por la mezcla.

En primer lugar, se observa que la incorporación del filler mineral reduce los huecos de la mezcla, mientras que la adición de polvo de neumático los aumenta. La mezcla sin filler tiene un $26,8 \%$ de huecos, la mezcla con polvo mineral un $23,7 \%$ para la relación $\mathrm{Cv} / \mathrm{Cs}=1 \mathrm{y}$, para esta misma relación volumétrica, la mezcla fabricada con el polvo de neumático tiene un $28,0 \%$. Es como si el polvo añadido, en el caso del filler mineral, se incorporara al betún pero sin dificultar la compactación de la mezcla, rellenando los huecos dejados por el árido grueso. En el caso del polvo de neumático es como si se hubiese formado una película de un mayor grosor que envuelve a las partículas y dificulta su aproximación.

Por el contrario, la adición de SBS apenas modifica el porcentaje de huecos de la mezcla respecto a la del betún base 0 la reduce ligeramente.

Las curvas de estado de los diferentes másticos están prácticamente en concordancia con la porosidad de las formulaciones ensayadas. La que mejor respuesta tiene es la fabricada con el filler mineral y la que peor, la fabricada con el polvo de neumático y una relación $\mathrm{Cv} / \mathrm{Cs}=1$. Parece como si el mástico producido por el polvo de neumático fuese menos tenaz y consistente que el betún original o el obtenido añadiendo SBS o filler mineral.

\section{ANALYSIS OF RESULTS}

\section{Dry mix process}

The UCL results for dry mix process crumb rubber modified bitumen are shown in Figure 2, which gives the voids content in the mix.

The voids content was observed to fall with the mineral filler and risse with the crumb rubber. The voids content in the mix with no filler was $26.8 \%$, in the asphalt with mineral filler and a CV/Cs ratio of $1,23.7 \%$, and in the mix made with crumb rubber, also having a $\mathrm{Cv} / \mathrm{Cs}$ volume ratio of one, $28.0 \%$. In other words, the mineral filler appear to blend with the bitumen without obstructing mix compaction, filling the gaps left by the coarse aggregate. In the case of crumb rubber by contrast, the result appears to be the formation of a thicker film that envelopes the particles and prevents them from clustering.

Finally, the addition of SBS barely modifies or at best slightly lowers the voids content in the base mix.

The performance curves for the various mastics are practically consistent with the porosity of the mixes tested. The best response was obtained with the bitumen containing mineral filler and the worst with crumb rubber and a CV/Cs ratio of 1. The mastic made with crumb rubber appears to be less tough and less consistent than both the original bitumen and the mastic obtained by adding SBS or mineral filler.

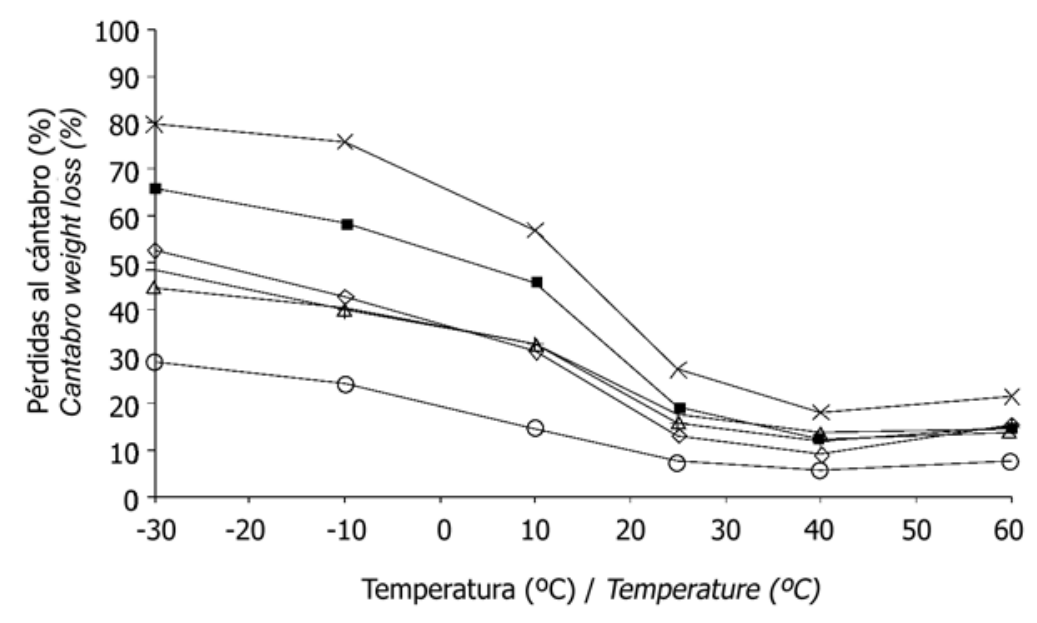

Sin filler; $26,8 \%$ huecos (No filler; $26.8 \%$ voids) $\mathrm{Cv} / \mathrm{Cs}=0,5 ; 28,0 \%$ huecos

(Cv/Cs $=0.5 ; 28.0 \%$ voids) $\mathrm{Cv} / \mathrm{Cs}=1 ; 28,0 \%$ huecos (Cv/Cs $=1 ; 28.0 \%$ voids) $\mathrm{Cv} / \mathrm{Cs}=1 ;$ Filler $\mathrm{CaCO}_{3} ; 23,7 \% \mathrm{~h}$. (Cv/Cs= 1 ; Filler $\mathrm{CaCO}_{3} ; 23.7 \%$ v.) SBS $=3,71 \mathrm{~g} ; 26,7 \%$ huecos (SBS $=3.71 \mathrm{~g} ; 26.7 \%$ voids) SBS $=8,03 \mathrm{~g} ; 25,9 \%$ huecos (SBS $=8.03 \mathrm{~g} ; 25.9 \%$ voids)

Figura 2. Curvas de comportamiento UCL. Betún B-60/70. Procedimiento vía seca. Figure 2. UCL performance curves. B-60/70 bitumen. Dry mix process. 


\section{Vía seca con digestión}

Un factor que puede resultar positivo para mejorar el efecto del polvo de neumático por vía seca es mantener la mezcla fabricada en reposo a una elevada temperatura, antes de su extendido y compactación. Es por ello que las mezclas fabricadas con el polvo de neumático y una relación $\mathrm{Cv} / \mathrm{Cs}=0,5$, se han mantenido durante 1 y 2 horas a $165 \stackrel{\circ}{ } \mathrm{C}$ antes de proceder a su compactación y fabricación de las probetas. Las series así fabricadas han sido ensayadas en el cántabro a las temperaturas antes señaladas, siguiendo el método UCL, habiéndose obtenido sus curvas de estado, Figura 3. En ella se observa que el tiempo de digestión puede tener una influencia positiva en la cohesión del ligante, que aumenta su resistencia a la disgregación con el tiempo de digestión, pero no sobre la compacidad de la mezcla que prácticamente se mantiene constante.

\section{Vía húmeda}

La adición de polvo de neumático por vía húmeda, tanto si se hace por mezclado por agitación (en el laboratorio), como si es por dispersión microscópica (elaborado en planta), tiene un efecto positivo.

En la Figura 4 se representan las curvas de estado para el betún modificado fabricado en el laboratorio a partir del betún base, añadiendo un 10, 15 y 20\% de peso de polvo de neumático sobre betún. En esta gráfica se ha representado también la curva de estado del betún BmPN. En ellas puede observarse que la adición del polvo de neumático por agitación tiene un efecto positivo que aumenta con la cantidad añadida.

\section{Dry mix process with digestion}

A technique that may improve the impact of adding crumb rubber with a dry mix process is high temperature storage of the mix prior to laying and compaction. To test this possibility, the mixes made with crumb rubber and a CV/Cs ratio of 0.5 were stored at $165{ }^{\circ} \mathrm{C}$ for one or two hours prior to compaction and manufacture of the specimens. These series were Cantabro tested at the above temperatures with the UCL method and their performance curves obtained as shown in Figure 3. The graphs are indicative of the beneficial effect of digestion time on binder cohesion, as the capacity of the mastic to resist disintegration rises with digestion time. This parameter is not observed to affect mix compactness, however, which remains practically unchanged.

\section{Wet mix process}

The wet mix addition of crumb rubber to bitumen is also observed to have a beneficial effect, whether laboratory mixing or industrial microscopic dispersion techniques are used.

Figure 4 depicts the performance curves for laboratorymodified bitumen containing 10, 15 and 20\% of crumb rubber (by weight of bitumen) as well as for industrially manufactured CRMB. These curves show that the improvement in performance afforded by crumb rubber increases with the amount of rubber added.

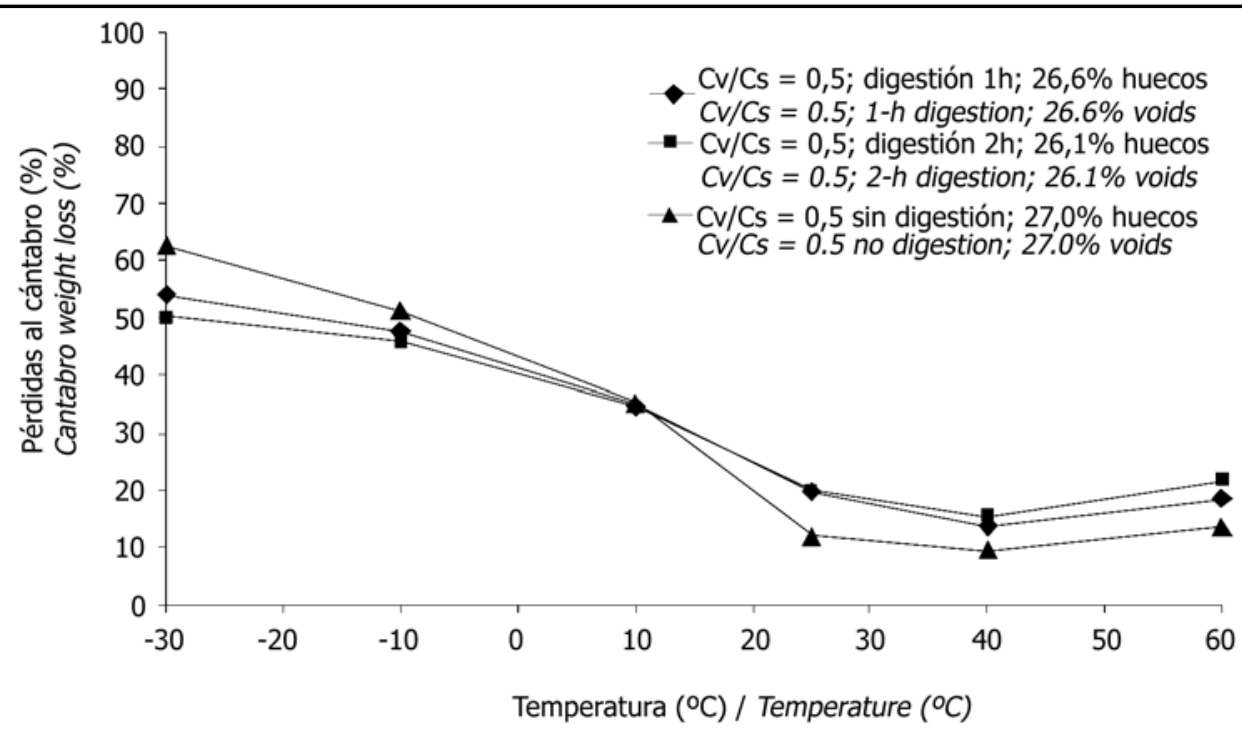

Figura 3. Curvas de comportamiento. Betún B-60/70. Procedimiento vía seca con digestión. Figure 3. UCL performance curves. B-60/70 bitumen. Dry mix process, with digestion. 


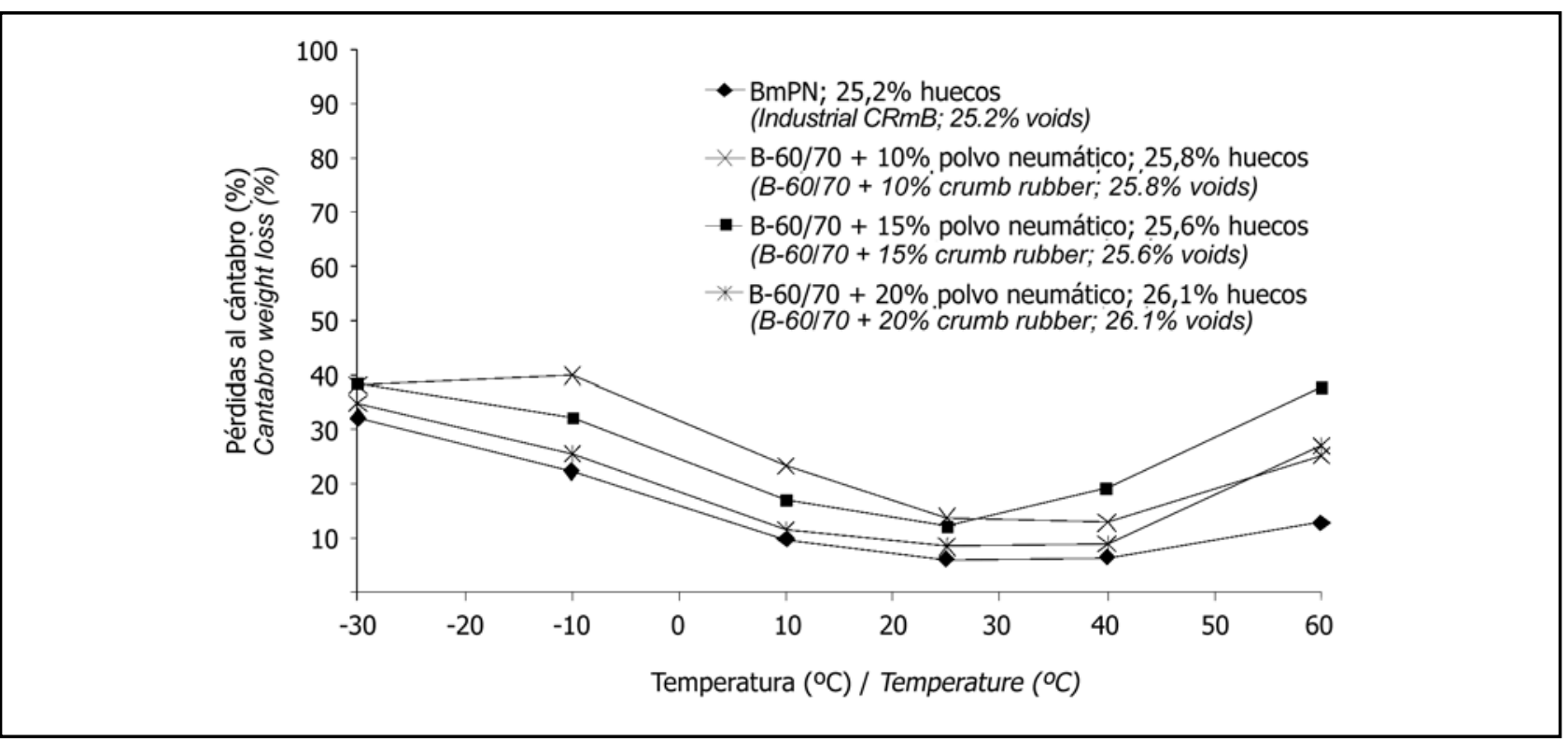

Figura 4. Curvas de comportamiento. Betunes B-60/70 y modificado. Procedimiento vía húmeda. Figure 4. UCL performance curves. B-60/70 bitumen and industrial CRMB. Wet mix process.

El betún BmPN preparado por dispersión microscópica presenta todavía unas mejores características. Su respuesta puede considerarse similar a la de algunos betunes modificados analizados por este procedimiento.

\section{CONCLUSIONES}

Los resultados obtenidos en la evaluación del efecto de la incorporación de polvo de neumático a los betunes pone de manifiesto:

- Vía seca, sin digestión: la adición del polvo de neumático disminuye la compacidad de las mezclas con él fabricadas. Parece como si aumentara el espesor de la película de ligante que envuelve los áridos, aumentando su separación y disminuyendo la compacidad de la mezcla. El mástico así formado, ligante más polvo de neumático, tiene una menor capacidad aglomerante que el betún original, de manera que da mayores pérdidas al cántabro, disminuyendo su cohesión.

- Vía seca con digestión: mantener la mezcla fabricada por vía seca en reposo a 165 ㄷ C durante 102 horas tiene un efecto positivo sobre el poder aglomerante del ligante, aunque no mejora su compactabilidad. Las pérdidas en el cántabro disminuyen, para las mezclas fabricadas con los betunes con polvo de neumático, pero mantienen una alta porosidad, similar a las fabricadas sin digestión.

- Vía húmeda: el efecto del polvo de neumático es más favorable si su incorporación se hace por vía húmeda. Tanto los betunes fabricados en laboratorio por agitación, como el fabricado en planta por dispersión
Even greater improvements are found with industrially prepared CRMB. Its response may be considered to be similar to the response of some types of modified bitumen analyzed with this procedure.

\section{CONCLUSIONS}

The results obtained from the evaluation of the impact of adding crumb rubber to bitumen show:

- Dry mix process without digestion: the addition of crumb rubber reduces the compactness of the mixes made with this component. The binder membrane enveloping the aggregate appears to thicken, increasing the spacing between particles and lowering the compactness of the mix. The mastic formed, consisting of the binder plus the crumb rubber, has lower bonding capacity than the bitumen alone; the greater weight loss observed in the cantabro test is indicative of weaker cohesion.

- Dry mix process with digestion: Exposing the dry mix process asphalt to a temperature of $165^{\circ} \mathrm{C}$ for one or two hours raises the bonding power of the binder but does not improve its compactability. The cantabro test weight loss is smaller for mixes made with crumb rubber modified bitumen but, as in the undigested product, porosity remains high.

- Wet mix process: the impact of crumb rubber is more effective if the wet mix process is used. The bitumen, whether made in a laboratory mixer or industrially with microscopic dispersion, has greater bonding power 
microscópica, presentan un mayor poder aglomerante que los betunes base. Las mezclas fabricadas con ellos presentan la misma compacidad que las fabricadas con el betún base. La comparación de los tres procedimientos empleados, vía seca con y sin digestión y vía húmeda, pone de manifiesto las ventajas de la vía húmeda, sobre todo cuando se lleva a cabo por dispersión microscópica.

\section{AGRADECIMIENTOS}

Los autores desearían agradecer la ayuda del Ministerio de Fomento y de la empresa Repsol YPF. than the base bitumen. Moreover, the mixes made with these materials are as compact as the ones made with base bitumen. The comparison of the three procedures used, the dry mix process with and without digestion and the wet mix process, reveals the greater effectiveness of the wet mix process, particularly when the rubber is microscopically dispersed.

\section{ACKNOWLEDGEMENTS}

This research was funded by the Spanish Ministry of Internal Development and Repsol YPF.

\section{BIBLIOGRAFÍA I BIBLIOGRAPHY}

(1) Kirk, J. van; Holleran, G.: "Reduced Thickness Asphalt Rubber Concrete Leads to Cost Effective Pavement Rehabilitation", $1^{\text {st }}$ International Conference World of Pavements, Sydney, 2000.

(2) Epps, J.: Uses of Recycled Rubber Tires in Highways. NCHRP Synthesis 198, Transportation Research Board, National Research Coun-

cil, Washington DC, 1994.

(3) Hicks, R. G.; Lundy, J. R.; Lehy, R. B.; Hanson, D.; Epps, J.: Crumb rubber modifier in asphalt pavement-Summary of practices in Arizona, California and Florida. Report № FHWA-SA-95-056, Federal Highway Administration, Washington DC, 1995.

(4) Leto, M.; Salini, R.: "Study of recycled tyre rubber in asphalt concrete mixtures", Proceedings of the Asphalt Rubber 2000, Vilamoura, Portugal (2000), pp. 341-357.

(5) Zboroswki, A.; Sotil, A.; Kaloush, K.: "Material characteristics of asphalt rubber mixtures", 83th Transportation Research Board Annual Meeting, Washington DC, 2004.

(6) Kaloush, K.; Witczak, M.; Sotil, A.: "Laboratory evaluation of asphalt rubber mixtures using the dynamic modulus ( $\left.E^{*}\right)$ test", $82^{\text {th }}$ Transportation Research Board Annual Meeting, Washington DC (2003).

(7) Pérez-J iménez, F.; Gordillo, J.: "Optimization of Porous Mixes Through the Use of Special Binders. Transportation Research Record", Journal of the Transportation Research Board, No. 1265 (1990), National Research Council, Washington DC, pp. 59-68.

(8) Ruiz, A.; Alberola, R.; Pérez-J iménez, F.; Sánchez, B.: "Porous Asphalt Mixtures in Spain Transportation Research Record", Journal of the Transportation Research Board, No. 1265 (1990), National Research Council, Washington DC, pp. 87-94.

(9) Pérez-J iménez, F.; Miró Recasens, R.: "Characterization procedure of Asphalt Binders with the Cántabro Test: UCL Method", $5^{\text {th }}$ Eurobitume Congress, Stockholm, Volume 1 (1993), pp. 209-213.

(10) Miró Recasens, R.: Metodología para la caracterización de ligantes asfálticos mediante el empleo del ensayo cántabro. PhD Thesis, Technical University of Catalonia, Barcelona, Spain (1994).

(11) Khalid, H. A.; Walsh, C. M.; Pérez-J iménez, F.; Miró Recasens, R.: "Rheological and Mechanical Characterization of Aged and Unaged Porous Asphalt Binders", Proceedings of the Institution of Civil Engineers, Transport, 129 (1998), pp. 240-246.

(12) Anderson, J. et al.: "Asphalt rubber laboratory properties related to type of process technology of crumb rubber", Proceedings of Asphalt-Rubber Congress 2000, Vilamoura, Portugal (2000) pp. 361-370.

(13) Pérez-J iménez, F. ; Miró Recasens, R.: "Caractérisation mécanique de liants asphaltiques: méthode UCL", Proceedings of the fifth RILEM Symposium MTBM, Lyon (1997), pp. 41-46.

(14) Ruiz, C.: Concentración Crítica de Filler, su Origen y Significado en la Dosificación de Mezclas Abiertas. Dirección de Vialidad de la Provincia de Buenos Aires, Publicación no 11 (1960), Buenos Aires, Argentina.

(15) Dorfman, B.; Rivara, Y.: "Sobre la Utilización de Filler en las Mezclas Asfálticas en Caliente", $x$ Congreso Argentino de Vialidad y Tránsito. Buenos Aires (1985), pp. 467-484. 